\title{
Students' unjustified study delays in general education and vocational education institutions in Latvia
}

\author{
I.J. Mihailovs \\ Rīga Stradinš̌ University, Rīga, Latvia
}

\begin{abstract}
Unjustified study delays in general education and vocational education institutions is one of the essential education institution problems, directly threatening not only the educational, pedagogical process and the quality of education in general, but also becoming the basis for a number of wide ranging problems, including leaving the education early, a diverse range of violation, but more broadly - delaying the achievement of the education's - compulsory secondary education - strategic goal. The article analyzes the current pedagogical and legal issues of absence prevention and gives suggestions for the unjustified absence monitoring and for the improvement of absence registration.
\end{abstract}

Unjustified study delays in general education and vocational education institutions is one of the essential problems in Latvian education operating, directly affecting not only the teaching, educational process and the quality of education in general, but also becoming the basis for a number of problems in larger scale, not only in education, but in the society in general, including early leaving of education and the absentees diverse offenses. Thus it requires resources to prevent the absence and also to support students that are absent.

At the same time this absence directly threatens the achievement of country's strategic objective - compulsory secondary education (Dālderis), as well as delays the objective of "Europe 2020" - until 2020 to achieve that the number of higher education graduates comprises $40 \%$ of the population.

Taking into account this, the article analyzes education management and legal aspects of student's unjustified absence prevention, and also outlines suggestions for implementation of absence monitoring in Latvia.

It should be noted that the problem of unjustified absence is rather old in education. For example, in 1934 the Law "On National Education" states that: "17. If the student has unjustified absence, the parents or teachers, or guardians, or employers are fined up to 1 lat for each absent day "(Aušeiks). Also, in the so-called "Soviet phase" problems of absence and discipline were topics of researcher work in pedagogy (Šmite, 2015).

After restoration of independence in the Republic of Latvia research of the unjustified absenteeism and early drop-out has been topical from the beginning of the 21 st century. Several studies have found that unjustified absenteeism and early drop-outs are determined by a number of external and internal factors: insufficient amount of educational institutions and parental cooperation, teachers' professional constraints, non-compliance of educational programs, books and methods with the present, attitude in media, relatively low value of education in children and young people's value system promoting the idea that education 
does not provide income, student's lack of skills to learn, different problems of socializing (Dedze, Krūzmēra, Mikiško; Maslo, Gonsalez, 2015).

Recognizing the unjustified absence as a serious problem, including in the context of compulsory primary education, it should be noted that the Latvian government still does not have accurate data about the absentees and about actions of schools and municipalities to prevent unjustified delays. In this context, it should be noted that studying policy planning and implementation process it is often ignored that there are two different groups of absentees in Latvia:

1. Compulsory school-age children who for various reasons are not registered in the lists of educational institutions, i.e., for various reasons, "have not been able to attend school"

2. Children and young people who are registered in the lists of educational institutions, but who for various reasons have unjustifiable attendance.

In 2010, in the legislative level of National Education Information System the learner records have been established, meaning that each of the general and vocational education institution provides information about their students in the system. Four times a year this entered information is compared with population register data of The Office of Citizenship and Migration Affairs, respectively, checking if all compulsory school-age Latvian children are in the lists of educational institutions. If it is found that a person in this age group is not registered in any educational institution on the list, the public administration institution - State Service of Education Quality of the Republic of Latvia - communicates with the municipality in which the person's place of residence is declared, and provides information on the situation.

Municipalities in cooperation with The State Social Insurance Agency, municipal civil registry department and the police department are obligated to check the received information in order to determine the causes of absence in educational institution and to address the issues of obtaining compulsory education (Regulations No. 788 of the Cabinet by August 17, 2010).

The data comparison (see Table 1) shows that since 2010 the number of unregistered children in educational institutions has gradually increased. According to information provided by local authorities, most of the unregistered in educational institutions children of compulsory education age are living abroad and the number is increasing every year. Since 2010 the number of children living abroad has increased by 7302, and in 2014 the number is 12948. However, there is a significant decrease in the number of children on who the municipalities have no information, as well as a decrease in number of children with longterm illness and the number of children with unclear status.

However, the Regulations No. 89 of the Cabinet of Ministers of February 1, 2011, "The procedure how education institutions inform parents, local or national authorities, if the student without a legitimate reason does not attend the educational institution" obliges the school to record absenteeism and "if the student has not attended preschool for more than three work days or more than 20 teaching hours per semester in general or vocational education institution and the institution has no information about the reason of absence or reason is not regarded as justifiable" to inform the local government, which should identify and eliminate causes of delay.

Information from 119 Latvian Republic municipalities about unjustified absenteeism in general education and vocational education institutions shows that in the 2 nd semester of the school year 2013/2014, 5469 students were unjustifiably absent in lessons, including 2644 students studying in general primary education programs, 1394 students - general secondary education programs, but 1127 - in vocational secondary education programs. In the 1 st semester of the school year 2014/2015 3850 students were unjustifiably absent in lessons, 
Table 1. Information provided by the municipalities on children of the compulsory education age not registered in any of the educational institutions 2010 - 2014 (State Education Quality Service) (Source: State service of Education Quality of the Republic of Latvia collected information).

\begin{tabular}{|l|c|c|c|c|c|}
\hline Status & \multicolumn{5}{|c|}{ Year } \\
\hline & $\mathbf{2 0 1 0}$ & $\mathbf{2 0 1 1}$ & $\mathbf{2 0 1 2}$ & $\mathbf{2 0 1 3}$ & $\mathbf{2 0 1 4}$ \\
\hline Departed from country & 5646 & 7915 & 9716 & 12218 & 12948 \\
\hline The municipality has no information & 4484 & 3327 & 2648 & 393 & 427 \\
\hline Permit of residence, foreign citizen* & & & & 894 & 1655 \\
\hline Annulled the declared residence & 670 & 763 & 61 & 115 & 186 \\
\hline $\begin{array}{l}\text { Does not attend an educational } \\
\text { institution for other reasons }\end{array}$ & 214 & 286 & 52 & 42 & 70 \\
\hline Disabled & 199 & 72 & 23 & 12 & 13 \\
\hline Missing (person) & 71 & 42 & 21 & 22 & 44 \\
\hline Adopted (abroad) & 31 & 8 & 29 & 39 & 46 \\
\hline Lasting illness & 11 & 9 & 3 & 6 & 1 \\
\hline The municipality has not indicated status & 0 & 0 & 65 & 176 & 92 \\
\hline Arrived from abroad & 0 & 41 & 0 & 0 & 0 \\
\hline The municipality is assessing situation & 0 & 0 & 0 & 256 & 211 \\
\hline Total & $\mathbf{1 1 3 2 7}$ & $\mathbf{1 2 4 6 3}$ & $\mathbf{1 2 6 1 8}$ & $\mathbf{1 4 1 7 3}$ & $\mathbf{1 5 6 9 3}$ \\
\hline
\end{tabular}

*Status introduced from 2013.

most of them (1690) - in general primary education programs. In the 2 nd semester of the school year 2014/ 2015 till 1st March, the information provided by local authorities reveals that 3166 students were unjustifiably absent including 1298 - from general primary education programs (see Table 2 - in appendix). Most of the absentees in all three semesters are from cities - Liepāja, Rīga and Valmiera.

Comparing the number of unjustifiably absent students in cities of the Republic and in the country, it appears that most of the absentees in all of the semesters at each level of education, excluding vocational secondary education, come from country municipalities, but compared by planning regions, most unjustified absentees come from Kurzeme planning region and Vidzeme planning region.

The majority of local governments associate the unjustified absences with the student's family, including the parents' inability to ensure that their children attend school regularly, denial of problems and unwillingness to cooperate with the educational institution, as well as parental irresponsibility and lack of interest in the child to pursue education. Even after the Ministry of Education had ordered from the Baltic Institute of Social Sciences "Research on causes and risks of early dropout from school in young people aged between 13 and 18 years" results show that the dominant causes of early dropout risk and unjustified absence in all levels of education is the insufficient parental involvement and control over the children's learning process.

Among the most commonly referred problems it is necessary to highlight the fact that educational institutions have difficulties to reach the students' parents, because they do not respond to phone calls or often change the phone number for various reasons, also the parents do not orderly notify the education institution about absences and the reasons for them, parents or students themselves forget to submit absence passes or submit them with a long delay, parents write a justifying pass even if there are no valid reasons. The circumstances that the parents work abroad or in a different region and persons who supervise the students, are unable to control the children, and make sure of school attendance, contribute to the problem. In addition, regular school attendance is affected by the family's financial situation - the lack of money for public transport, food and clothing.

The second group of problems is related to students themselves. For example, there are under-aged students who are living separately from their parents are working or have 
already formed a family and are raising their own children. Several students with unjustifiable absenteeism experience lack of motivation to learn and to reduce absenteeism, they have a variety of addictions and behavioural disorders. The already mentioned Baltic Institute of Social Sciences research study found that lack of motivation to learn is one of the main reasons of unjustified absenteeism and thus the risk of early dropout from school.

Another group of problems is related to shortcomings in the regulations and gaps in local financing, i.e., the lack of sanctions against parents and students to ensure that students attend school regularly, as for parents - to inform about the delays on time and keep track of their children's educational process. There is no procedure for preventing unjustified absence in the regulations that regard to persons who have reached 18 years of age.

Similarly, local governments find it a problem that the legislation does not set the limited number of absent lessons that parents are eligible to justify.

Several local governments refer to the lack of funding to hire the supporting staff for teaching work in the educational institutions, because the supporting staff and class teachers could ensure immediate, regular and purposeful work with the absentees. Deficiency of resources (human, financial, time) also delays the implementation of measures for preventing absenteeism and for keeping records of it. Several local governments rely on the results for school network optimization - if the school is far away from home, it is not being attended more often.

Overall, it should be pointed out that unjustified absence from lessons is a complex problem which should be addressed at the municipal level by inter-institutional co-operation committee (involving the responsible state and municipal service representatives). In this context, it should be noted that social workers and social teachers still have insufficient knowledge of the prevention of absenteeism, applicable normative regulations and the principles of cooperation. This is also evidenced by the fact that in one of the social workers textbooks, dedicated to the prevention of absenteeism, the Cabinet of Ministers regulations are not even mentioned (Birǵele, Ševele, 2015).

There are also problems of student's unjustified absenteeism records in the vocational education, because often the student is declared in one municipality, but the educational institution is located in another municipality.

At the same time it should be noted that the information provided by municipalities on absenteeism and its prevention should be evaluated critically, questioning the reliability of this data. As shown by the OECD PISA 2012 study in Latvia, in which 1407 15-yearolds were surveyed, $19.5 \%$ of the students attending schools in Riga, before the study in the last two weeks were absent from school for a full day (OECD (Organisation for Economic Cooperation and Development. PISA (The Programme for International Student Assessment). OECD PISA 2012 study was carried out by the State Education Development Agency in cooperation with the Faculty of Pedagogy and Psychology of the University of Latvia and Art's Education research institute researchers (Grīnfelds).

Riga City Council's Welfare Department commissioned Market and Social Research Institute "Latvian Facts" in 2014 and by the survey found that $20 \%$ of 15 to 16 -year-olds do not attend school by "playing hooky", but $56 \%$ of 9th-10th grade students do not attend school for various reasons, while the State Service of Education Quality in 2014 conducted an analytical study "General education student absenteeism and actions to prevent them" shows that $22 \%$ of the 1765 respondents in general education institution grades 6, 9 and 11 are absent in at least one lesson per week that is unjustified.

To solve the problems associated with unjustified non-attendance records and problems to prevent this absenteeism, it is needed to provide the resources for continuous monitoring of the unjustifiably absent students not only locally but also on the state level, including administration of the unjustified absenteeism data in the National Education Information System. 
To prevent irrational use of governmental funds in cases where students are absent for a long period of time for unjustified reasons, because the state allocates resources to fund each registered student in the educational institution, but the state is not aware whether the students actually attends school and learns. It would also be necessary to ensure the monitoring of unjustified attendance of students who have reached full age (because currently in Latvia the students who are of legal age do not have a factual obligation to attend school). At the same time, there is no current mechanism to record the attendance (and also the absence of it).

\section{References}

\section{Literature}

[1] Birǵele, E., Ševele, I. (2015) Sociālo darbinieku un sociālo pedagogu sadarbība darbā ar ǵimenēm, kuras bērni ilgstoši neapmeklē skolu: laba pieredze. Rīga: Aisma, 45 lpp.

[2] Maslo, I., Gonsalez, M., F. (2015) Supporting the engagement and reintegration of 18-24 year old early school-livers in lifelong learning: evidences for targeted compensatory and preventive strategy in education. Rīga: University of Latvia, 505 p.

[3] Šmite, A. (2015) Pedagoǵisko darbinieku tālākizglīīiba Latvijā. Rīga: Raka, 320 lpp.

\section{Internet resources}

[4] Aušeiks, G. Īsumā par izglītību, skolotājiem un viņu darbu Latvijā no 1919. līdz 1940. gadam. Pieejams: http://alv.lv/lv/biblioteka/isuma-par-izglitibu-lat vija-krievijas-imperijas-sa/ [pēdējo reizi sk. 10.07.2015.].

[5] Dālderis I. Obligāta vidējā izglītība - ekonomikai un tautas intelektam. Pieejams: http://www.delfi.lv/news/comment/comment/ints-dalderis-obligata-vi deja-izglitiba-ekonomikai-un-tautas-intelektam.d?id=46132439\#ixzz 3dm210z44 [pēdējo reizi sk. 10.07.2015.].

[6] Dedze, I., Krūzmēra, M., Mikiško, I. Savlaicīgu pamatizglītības apguvi traucējošo faktoru kopums. Piejams: http://providus.lv/article/savlaicigupamatizglitibas-apguvi-traucejoso-faktoru-kopums [pēdējo reizi sk. 10.07.2015.].

[7] Eiropa 2020. Stratēǵija gudrai, ilgtspējīgai un integrējošai izaugsmei. Pieejams: http://ec.europa.eu/eu2020/pdf/1_LV_ACT_part1_v1.pdf [pēdējo reizi sk. 10.07.2015.].

[8] Grīnfelds, A. Skolas kavēšana un skolenu sasniegumi OECD PISA 2012. Pieejams: http://www.ipi.lu.lv/uploads/media/SkolasKavesana_Grinfelds.pdf [pēdējo reizi sk. 10.07.2015.].

[9] Izglītības kvaliātes valsts dienesta 2014.gada Publiskais pārskats. Pieejams: http:// www.ikvd.gov.lv/assets/files/2013/citi/2015/2014_gada.pdf [pēdējo reizi sk. 10.07.2015.].

[10] Ministru kabineta 2011.gada 1.februāra noteikumi Nr.89 "Kārtība, kādā izglītības iestāde informē izglītojamo vecākus, pašvaldības vai valsts iestādes, ja izglītojamais bez attaisnojoša iemesla neapmeklē izglītības iestādi”. Pieejams: http://likumi . $l \mathrm{v} /$ doc $\cdot$ php? id=225270 [pēdējo reizi sk. 10.07.2015.].

[11] Ministru kabineta 2009.gada 4.augusta noteikumi Nr.871 "Obligāto izglītības vecumu sasniegušo bērnu uzskaites kārtība”. Pieejams: http://likumi.lv/ doc.php?id=195933 [pēdējo reizi sk. 10.07.2015.].

[12] Ministru kabineta 2010.gada 17.augusta noteikumi Nr.788 "Valsts izglītības informācijas sistēmas saturs, uzturēšanas un aktualizācijas kārtība". Pieejams: http://likumi.lv/doc.php?id=215853 [pēdējo reizi sk. 10.07.2015.]. 
[13] Pētījums par priekšlaicīgas mācību pamešanas iemesliem un riskiem jauniešiem vecuma grupā no 13 līdz 18 gadiem. Piejams: http: //www.izm.gov.lv/images/ statistika/petijumi/41.pdf [pēdējo reizi sk. 10.07.2015.].

[14] Pētījuma ziņojums "Riska un aizsargājošo faktoru ietekme uz atkarību izraisošo vielu lietošanas līmeni jauniešu vidū. 5.posms". Pieejams: http:// www . veseligsridzinieks. lv/wp-content/uploads/2015/03/Riska-faktoru -ietekme_atkaribu-izraisosas-vielas_Rezultatu-atskaite_2014.pdf [pēdējo reizi sk. 10.07.2015.].

[15] Ziņojums par analītisko izpēti "Vispārējās izglītības iestāžu izglītojamo kavējumi un rīcība to novēršanai". Pieejams: http://ikvd.gov.lv/assets/files/2013/ citi/Zinojums_kavejumi_09.2014..pdf [pēdējo reizi sk. 10.07.2015.].

\section{Appendix}

Table 2. Unjustified attendance in Latvian Education institutions in the 2nd semester of 2013/2014 school year and till 1st March of 2014/2015 school year. (Source: State Service of Education Quality of the Republic of Latvia collected information).

\begin{tabular}{|l|c|c|c|c|}
\hline \multirow{2}{*}{$\begin{array}{l}\text { Educational } \\
\text { programs }\end{array}$} & \multicolumn{4}{|c|}{$\begin{array}{c}\text { Amount of students who have not attended preschool } \\
\text { for more than three work days or more than 20 teaching hours } \\
\text { per semester in general or vocational education institution }\end{array}$} \\
\cline { 2 - 5 } & $\mathbf{2 0 1 3 / 2 0 1 4}$ school year & \multicolumn{2}{|c|}{$\mathbf{2 0 1 4 / 2 0 1 5}$ school year } \\
\cline { 2 - 5 } & $\mathbf{1 s t}$ semester & $\begin{array}{c}\text { 2nd } \\
\text { semester }\end{array}$ & $\mathbf{1 s t}$ semester & $\begin{array}{c}\text { 2nd semester } \\
\text { (till 1st March) }\end{array}$ \\
\hline Preschool & 290 & 245 & 230 & 170 \\
\hline $\begin{array}{l}\text { General primary } \\
\text { education }\end{array}$ & 1712 & 2644 & 1690 & 1298 \\
\hline $\begin{array}{l}\text { General secondary } \\
\text { education }\end{array}$ & 843 & 1394 & 784 & 740 \\
\hline $\begin{array}{l}\text { Vocational primary } \\
\text { education }\end{array}$ & 843 & 1394 & 784 & 740 \\
\hline $\begin{array}{l}\text { Vocational secondary } \\
\text { education }\end{array}$ & 52 & 59 & 47 & 23 \\
\hline TOTAL: & 358 & 1127 & 1099 & $\mathbf{3 1 6 6}$ \\
\hline
\end{tabular}

